\title{
Thermal regime and host clade, rather than geography, drive Symbiodinium and bacterial assemblages in the scleractinian coral Pocillopora damicornis sensu lato
}

Kelly Brener-Raffalli ${ }^{1}$, Camille Clerissi ${ }^{1}$, Jeremie Vidal-Dupiol ${ }^{1}$, Mehdi Adjeroud ${ }^{2}$, François Bonhomme ${ }^{3}$, Marine Pratlong ${ }^{4}$, Didier Aurelle ${ }^{4}$, Guillaume Mitta ${ }^{1}$ and Eve Toulza ${ }^{1 *}$

\begin{abstract}
Background: Although the term holobiont has been popularized in corals with the advent of the hologenome theory of evolution, the underlying concepts are still a matter of debate. Indeed, the relative contribution of host and environment and especially thermal regime in shaping the microbial communities should be examined carefully to evaluate the potential role of symbionts for holobiont adaptation in the context of global changes. We used the sessile, long-lived, symbiotic and environmentally sensitive reef-building coral Pocillopora damicornis to address these issues.

Results: We sampled Pocillopora damicornis colonies corresponding to two different mitochondrial lineages in different geographic areas displaying different thermal regimes: Djibouti, French Polynesia, New Caledonia, and Taiwan. The community composition of bacteria and the algal endosymbiont Symbiodinium were characterized using high-throughput sequencing of $16 \mathrm{~S}$ rRNA gene and internal transcribed spacer, ITS2, respectively. Bacterial microbiota was very diverse with high prevalence of Endozoicomonas, Arcobacter, and Acinetobacter in all samples. While Symbiodinium sub-clade C1 was dominant in Taiwan and New Caledonia, D1 was dominant in Djibouti and French Polynesia. Moreover, we also identified a high background diversity (i.e., with proportions $<1 \%)$ of $\mathrm{A} 1, \mathrm{C} 3, \mathrm{C} 15$, and $\mathrm{G}$ Symbiodinum sub-clades. Using redundancy analyses, we found that the effect of geography was very low for both communities and that host genotypes and temperatures differently influenced Symbiodinium and bacterial microbiota. Indeed, while the constraint of host haplotype was higher than temperatures on bacterial composition, we showed for the first time a strong relationship between the composition of Symbiodinium communities and minimal sea surface temperatures.
\end{abstract}

Conclusion: Because Symbiodinium assemblages are more constrained by the thermal regime than bacterial communities, we propose that their contribution to adaptive capacities of the holobiont to temperature changes might be higher than the influence of bacterial microbiota. Moreover, the link between Symbiodinium community composition and minimal temperatures suggests low relative fitness of clade $D$ at lower temperatures. This observation is particularly relevant in the context of climate change, since corals will face increasing temperatures as well as much frequent abnormal cold episodes in some areas of the world.

Keywords: Coral holobiont, Microbiota, Bacterial communities, Symbiodinium assemblages, Thermal adaptation, Scleractinian corals, Coral reefs, Pocillopora damicornis

\footnotetext{
* Correspondence: eve.toulza@univ-perp.fr

${ }^{1}$ IHPE, UMR 5244, University of Perpignan Via Domitia, CNRS, IFREMER,

University of Montpellier, Perpignan, France

Full list of author information is available at the end of the article
} 


\section{Background}

All partners (bionts) involved in a stable symbiosis, and thus being part of the entire organism, constitute the holobiont [1]. A decade after this term has been defined; it has been popularized in corals [2] and subsequently led to the hologenome theory of evolution [3-6]. The hologenome is defined as the sum of the genetic information of the host and its symbiotic microorganisms. In this context, phenotypes are the product of the collective genomes of the holobiont partners, being the true unit of biological organization and thus the object of natural selection [7-9]. This concept has gained increased attention for many issues on the functioning, homeostasis, or evolution of living organisms, extending our knowledge of microbial community associated to them (see [10] for a review on metaorganisms).

Scleractinian corals (the major reef-building organisms of coral reef ecosystems) are considered as the most diverse symbiotic ecosystem studied to date [11], forming a complex consortium composed by the cnidarian host, as well as microbial eukaryotes (including the dinoflagellate endosymbiont Symbiodinium), prokaryotes (bacteria and archae), and viruses. The symbiosis between corals and dinoflagellate algae of the genus Symbiodinium provides the foundation for the ecological success of coral reefs over millions of years [12]. In this phototrophic and potentially mutualistic association, the coral host provides inorganic nutrients in exchange of photosynthetically fixed carbon (photosynthates) and amino acids from the algal symbiont [12-14]. Algae from the Symbiodinium genus are classified into nine clades (from A to I) $[15,16]$, and the physiology of the coral holobiont is affected by the clade of the symbiont $[17,18]$. Although the establishment of a specific symbiosis occurs during early stages of host larvae colonization [19], some coral species can switch endosymbiotic algae during their lifetime in response to major environmental stressors such as thermally induced bleaching events [20,21], although the long-term persistence of such changes is matter of debate [22]. Bacterial communities associated to corals have also been extensively studied comparing different species [2, 23], disease states [24-26], or environmental conditions [27, 28] (see also [3] for a review).

Despite this large corpus of studies, none addressed the effect of natural thermal regimes on microbial assemblages in scleractinian corals. However, sea surface temperature increase is the main factor of ongoing climate changes affecting reef-building corals $32.8 \%$ of species being considered at risk of extinction) [29] with mass mortalities following severe and recurrent bleaching events [30].

In this study, we investigated the effect of thermal regimes, as well as host clade and geographical distribution, on the bacterial and Symbiodinium assemblages in the complex Pocillopora damicornis sensus lato (Veron and Pichon 1976), a functional group of environmentally sensitive scleractinian corals [31] that was recently split into five clades [32-34]. High-throughput metabarcoding allowed us to access for the first time the unculturable diversity of both bacterial communities and Symbiodinium assemblages in coral populations from different locations with contrasting thermal regimes.

\section{Methods}

\section{Sampling sites and study design}

Colonies of Pocillopora damicornis sensus lato growing between 1 and $5 \mathrm{~m}$ depth were sampled by snorkeling from four regions (Djibouti, Taiwan, New Caledonia, and French Polynesia [35]) in 15 localities (Table 1). A total of 94 colonies were sampled during this survey. The tip $(1-2 \mathrm{~cm})$ from one healthy branch of each colony was cut and disposed individually in a plastic bag held in seawater during the sampling cruise. Samples were subsequently transferred into modified CHAOS buffer (4 M

Table 1 Details of the sampling of Pocillopora damicornis sensu lato conducted in this study

\begin{tabular}{|c|c|c|c|c|c|}
\hline Region & Locality & Code & Latitude & Longitude & $\mathrm{Nb}$ \\
\hline \multirow[t]{3}{*}{ Djibouti } & Moucha Island & DJMI & $\begin{array}{l}11^{\circ} 43^{\prime} \\
49.27^{\prime \prime} \mathrm{N}\end{array}$ & $\begin{array}{l}43^{\circ} 13^{\prime} \\
26.69^{\prime \prime} \mathrm{E}\end{array}$ & 7 \\
\hline & Ras Korali & DJRK & $\begin{array}{l}11^{\circ} 46^{\prime} \\
46.15^{\prime \prime} \mathrm{N}\end{array}$ & $\begin{array}{l}42^{\circ} 55^{\prime} \\
27.65^{\prime \prime} \mathrm{E}\end{array}$ & 8 \\
\hline & Sable Blanc & DJSB & $\begin{array}{l}11^{\circ} 34^{\prime} \\
57.41^{\prime \prime} \mathrm{N}\end{array}$ & $\begin{array}{l}42^{\circ} 47^{\prime} \\
45.86^{\prime \prime} \mathrm{E}\end{array}$ & 12 \\
\hline \multirow[t]{6}{*}{$\begin{array}{l}\text { French } \\
\text { Polynesia }\end{array}$} & $\begin{array}{l}\text { Moorea island- } \\
\text { Papetoai }\end{array}$ & FPMP & $\begin{array}{l}17^{\circ} 29^{\prime} \\
31.72^{\prime \prime} \mathrm{S}\end{array}$ & $\begin{array}{l}149^{\circ} 52^{\prime} \\
8.34^{\prime \prime} \mathrm{O}\end{array}$ & 6 \\
\hline & $\begin{array}{l}\text { Moorea island- } \\
\text { Tiahura }\end{array}$ & FPMT & $\begin{array}{l}17^{\circ} 29^{\prime} \\
22.90^{\prime \prime} \mathrm{S}\end{array}$ & $\begin{array}{l}149^{\circ} 53^{\prime} \\
48.65^{\prime \prime} \mathrm{O}\end{array}$ & 5 \\
\hline & $\begin{array}{l}\text { Raiatea island- } \\
\text { Avera }\end{array}$ & FPRA & $\begin{array}{l}16^{\circ} 47^{\prime} \\
22.00^{\prime \prime} \mathrm{S}\end{array}$ & $\begin{array}{l}151^{\circ} 23^{\prime} \\
30.63^{\prime \prime} \mathrm{O}\end{array}$ & 8 \\
\hline & $\begin{array}{l}\text { Tahaa island- } \\
\text { Tapuamu }\end{array}$ & FPTT & $\begin{array}{l}16^{\circ} 36^{\prime} \\
51.03^{\prime \prime} \mathrm{S}\end{array}$ & $\begin{array}{l}151^{\circ} 32^{\prime} \\
33.91^{\prime \prime} \mathrm{O}\end{array}$ & 5 \\
\hline & $\begin{array}{l}\text { Tahaa island- } \\
\text { Vaitoare }\end{array}$ & FPTV & $\begin{array}{l}16^{\circ} 40^{\prime} \\
36.26^{\prime \prime} \mathrm{S}\end{array}$ & $\begin{array}{l}151^{\circ} 27^{\prime} \\
18.92^{\prime \prime} \mathrm{O}\end{array}$ & 9 \\
\hline & $\begin{array}{l}\text { Tahiti island-_ } \\
\text { Papeete }\end{array}$ & FPTP & $\begin{array}{l}17^{\circ} 34^{\prime} \\
27.93^{\prime \prime} \mathrm{S}\end{array}$ & $\begin{array}{l}149^{\circ} 37^{\prime} \\
11.07^{\prime \prime} \mathrm{O}\end{array}$ & 7 \\
\hline \multirow[t]{3}{*}{$\begin{array}{l}\text { New } \\
\text { Caledonia }\end{array}$} & $\begin{array}{l}\text { Baie de Ste. } \\
\text { Marie }\end{array}$ & NCBS & $\begin{array}{l}22^{\circ} 17^{\prime} \\
35.86^{\prime \prime} \mathrm{S}\end{array}$ & $\begin{array}{l}166^{\circ} 28^{\prime} \\
14.44^{\prime \prime} E\end{array}$ & 4 \\
\hline & $\begin{array}{l}\text { Baie de } \\
\text { Ma'a }\end{array}$ & NCBM & $\begin{array}{l}22^{\circ} 11^{\prime} \\
45.17^{\prime \prime} \mathrm{S}\end{array}$ & $\begin{array}{l}166^{\circ} 20^{\prime} \\
23.67^{\prime \prime} E\end{array}$ & 4 \\
\hline & $\begin{array}{l}\text { Grande } \\
\text { Rade }\end{array}$ & NCGR & $\begin{array}{l}22^{\circ} 14^{\prime} \\
38.63^{\prime \prime} \mathrm{S}\end{array}$ & $\begin{array}{l}166^{\circ} 25^{\prime} \\
7.58^{\prime \prime} E\end{array}$ & 6 \\
\hline \multirow[t]{3}{*}{ Taiwan } & Outlet & TWOU & $\begin{array}{l}21^{\circ} 55^{\prime} \\
48.4^{\prime \prime} \mathrm{N}\end{array}$ & $\begin{array}{l}120^{\circ} 44^{\prime} \\
41.9^{\prime \prime} \mathrm{E}\end{array}$ & 6 \\
\hline & Hobihu & TWHO & $\begin{array}{l}21^{\circ} 56^{\prime} \\
18.6^{\prime \prime} \mathrm{N}\end{array}$ & $\begin{array}{l}120^{\circ} 44^{\prime} \\
45.7^{\prime \prime} \mathrm{E}\end{array}$ & 4 \\
\hline & Wanliton & TWWA & $\begin{array}{l}21^{\circ} \\
59^{\prime} 37.7^{\prime \prime} \mathrm{N}\end{array}$ & $\begin{array}{l}120^{\circ} \\
42^{\prime} 22.7^{\prime \prime} \mathrm{E}\end{array}$ & 3 \\
\hline
\end{tabular}

$\mathrm{Nb}$ number of colonies sampled at each locality 
guanidium thiocyanate, $0.5 \% \mathrm{~N}$-lauryl sarcosine sodium $25 \mathrm{mM}$ Tris- $\mathrm{HCl} \mathrm{pH} \mathrm{8,0.1} \mathrm{M} \mathrm{b-mercaptoethanol)} \mathrm{as}$ described [36].

Thermal regime descriptors were compiled from weekly mean sea surface temperature data collected from IGOSS, Integrated Global Ocean Services System Products Bulletin (http://iridl.ldeo.columbia.edu/SOURCES/.IGOSS/) for quadrats of $1^{\circ}$ longitude $\times 1^{\circ}$ latitude and from 1982 to the year of sampling (2008-2009).

\section{DNA extraction}

DNA extraction was performed using CTAB (cetyl trimethylammonium bromide)-based extraction method [37]. Briefly, coral tips were lysed $2 \mathrm{~h}$ in $600 \mu \mathrm{L}$ CTAB buffer (2\% CTAB, $0.2 \% \beta$-mercaptoethanol, 1.4 M NaCI, $20 \mathrm{~mm}$ EDTA pH 8, I00 mm Tris- $\mathrm{HCl} \mathrm{pH} \mathrm{8,} 100 \mu \mathrm{g} / \mathrm{mL}$ proteinase $\mathrm{K})$ at $60^{\circ} \mathrm{C}$. An equal volume of chloroform:isoamyl-alcohol (24:1) was then added. After centrifugation for $10 \mathrm{~min}$ at $14,000 \mathrm{~g}$, the aqueous phase was transferred to a new tube and DNA was precipitated by adding $400 \mu \mathrm{L}$ of ice-cold isopropanol and incubating $1 \mathrm{~h}$ at $-20{ }^{\circ} \mathrm{C}$. After centrifugation for $15 \mathrm{~min}$ at $14,000 \mathrm{~g}$, the supernatant was discarded and the pellet washed with $70 \%$ ethanol. The pellet was air-dried for $5 \mathrm{~min}$ and resuspended in water.

\section{Host haplotype identification}

The mitochondrial variable open reading frame (ORF) was amplified with FATP6.1 (5'-TTTGGGSATTCGTTTA GCAG-3') and RORF (5'-SCCAATATGTTAAACASCA TGTCA-3') primers [38] and submitted to sanger sequencing (GenBank submission ID 2033564). Protein-coding sequences were analyzed using MEGA version 6 [39]. Sequence alignment was performed using MUSCLE. The best model (Kimura-2 parameters with uniform substitution rates) was selected for the lowest BIC (Bayesian Information Criterion). Maximum-likelihood tree was computed with the best model, and the robustness of the tree was tested with 1000 bootstrap replicates.

\section{S rRNA gene and internal transcribed spacer ITS2 metabarcoding}

For all 94 individual samples, amplicon sequencing was performed for the two markers separately. For bacterial communities, 16S rRNA gene libraries were generated using the 341F (5' -CCTACGGGNGGCWGCAG-3') and 805R (5'-GACTACHVGGGTATCTAATCC-3') primers targeting the variable V3V4 loops [40]. For each sample, a first PCR amplification of 35 cycles was performed for the generation of amplicons $\left(96{ }^{\circ} \mathrm{C}\right.$ for $30 \mathrm{~s}, 55^{\circ} \mathrm{C}$ for $30 \mathrm{~s}$, $72{ }^{\circ} \mathrm{C}$ for $1 \mathrm{~min}$ ) followed by 15 cycles with Illumina adaptors and sequencing index for thelibrary $\left(95{ }^{\circ} \mathrm{C}\right.$ for $15 \mathrm{~s}$, $58{ }^{\circ} \mathrm{C}$ for $30 \mathrm{~s}, 72{ }^{\circ} \mathrm{C}$ for $\left.1 \mathrm{~min}\right)$.
Symbiodinium assemblages were analyzed using ITS2 (internal transcribed spacer of the ribosomal RNA gene) amplicon libraries with specific primers targeting a 350 bp sequence: ITS2-F (5'-GTGAATTGCAGA ACTCCGTG-3') and ITS2-R (5'-CCTCCGCTTACTTA TATGCTT-3') [41, 42]. For each sample, a first PCR amplification of 35 cycles was performed for the generation of amplicons $\left(96{ }^{\circ} \mathrm{C}\right.$ for $30 \mathrm{~s}, 54{ }^{\circ} \mathrm{C}$ for $30 \mathrm{~s}, 72{ }^{\circ} \mathrm{C}$ for $1 \mathrm{~min}$ ) followed by 15 cycles with Illumina adaptors and sequencing index for the library $\left(95^{\circ} \mathrm{C}\right.$ for $15 \mathrm{~s}, 58^{\circ}$ $\mathrm{C}$ for $30 \mathrm{~s}, 72{ }^{\circ} \mathrm{C}$ for $1 \mathrm{~min}$ ).

For both $16 \mathrm{~S}$ rRNA gene and ITS2 markers, pairedend sequencing with 250 bp read length was performed on two different flow cells using the MiSeq system (Illumina) using the v2 chemistry according to the manufacturer's protocol. Sequencing was performed at the McGill University in the Génome Québec Innovation Centre, Montréal, Canada. Raw sequence data are available in the SRA database (BioProject ID PRJNA393088, BioSample ID SUB2829485).

\section{Sequence analysis of metabarcoding datasets}

The FROGS pipeline (Find Rapidly OTU with Galaxy Solution) implemented on a galaxy instance (http:// sigenae-workbench.toulouse.inra.fr/galaxy/) was used for data processing [43]. In brief, paired reads were merged using FLASH [44]. After denoising and primer/adapters removal with cutadapt [45], de novo clustering was done using SWARM that uses a local clustering threshold [46], with aggregation distance $d=3$ after denoising. Chimera were removed using VSEARCH [47]. We filtered the dataset for singletons and performed affiliation using Blast+ against the Silva database (release 128, September 2016) for $16 \mathrm{~S}$ rRNA gene amplicons. For ITS2 metabarcoding, the Symbiodinium clade was assessed using blastn best hit against the $\mathrm{nr} / \mathrm{nt}$ database of the NCBI [48]. To confirm blast identification, we performed phylogenetic analysis using MAFFT to produce sequence alignment and FastTree (GTR + CAT model) to compute tree with the approximately maximum-likelihood method. Finally, OTU tables were produced in a standard BIOM format for subsequent analyses.

\section{Statistical analyses}

All statistical analyses were done using $\mathrm{R}$ version 3.3.1 ([49], http://www.R-project.org). We used the phyloseq $\mathrm{R}$ package for community composition analysis [50] to infer alpha diversity metrics at the OTU level, as well as beta diversity (between sample distance) from the OTU table. Community similarity was assessed by principal coordinate analysis (PCoA) using the Bray-Curtis dissimilarity index.

We performed non-parametric Kruskal-Wallis tests (since normality of residuals and homogeneity of 
variances were rejected (Shapiro and Bartlett test, respectively)) to compare alpha diversity metrics (Chao1 and Shannon). When Kruskal-Wallis tests were significant, we then computed pairwise comparisons between group levels (post hoc analyses) with Bonferroni corrections for multiple testing using Dunn tests.

Redundancy analysis [51] (hereafter named RDA) was used to investigate the variations of the different bacterial OTU/Symbiodinium clades under the constraint of the environmental variables. Bacterial OTUs and Symbiodinium clades were Hellinger-transformed before performing RDAs [52] on datasets of geography, temperature, and host genotypes (Additional file 1: Table S1). Then significant variables (i.e., variables that significantly explained changes in the distribution of OTUs/clades) were identified using a forward-selection procedure (999 permutations), implemented in the $\mathrm{R}$ "vegan" package and in the "rda" and "ordiR2step" functions. For all analyses, the threshold significance level was set at 0.05 .

\section{Results \\ Sampling sites display diverse and contrasted thermal regimes}

To have a precise view of the thermal regimes in the different sampling sites, we extracted several descriptors over a long-term continuous monitoring (weekly) of mean sea surface temperature (SST) data. We computed the annual mean temperature and the minimum and maximum temperatures, as well as mean temperatures, for the three warmer or colder months over these timeseries records and annual temperature variance (Table 2, Fig. 1). We had very contrasted thermal regimes between the sampled regions with high and low annual variations in Taiwan and French Polynesia, respectively. The minimal temperatures were lower in New Caledonia and Taiwan compared to Djibouti and French Polynesia. The maximum temperatures were less contrasted with a more continuous increase from New Caledonia to French Polynesia, then Taiwan and Djibouti.

Table 2 Thermal regime descriptors of the four sampled regions calculated from weekly SST data (from 1982 to the year of sampling, 2008 or 2009, according to regions)

\begin{tabular}{lllll}
\hline & Djibouti & $\begin{array}{l}\text { French } \\
\text { Polynesia }\end{array}$ & $\begin{array}{l}\text { New } \\
\text { Caledonia }\end{array}$ & Taiwan \\
\hline Mean temperature $\left({ }^{\circ} \mathrm{C}\right)$ & 28.60 & 27.67 & 24.77 & 26.56 \\
Max temperature $\left({ }^{\circ} \mathrm{C}\right)$ & 32.20 & 29.95 & 28.78 & 30.83 \\
Min temperature $\left({ }^{\circ} \mathrm{C}\right)$ & 25.11 & 25.25 & 21.28 & 21.40 \\
$\begin{array}{l}\text { Mean of the warmer } \\
\text { months }\left({ }^{\circ} \mathrm{C}\right)\end{array}$ & 30.46 & 28.75 & 26.82 & 29.14 \\
$\begin{array}{l}\text { Mean of the colder } \\
\text { months }\left({ }^{\circ} \mathrm{C}\right)\end{array}$ & 26.32 & 26.51 & 22.81 & 23.88 \\
Variance $\left({ }^{\circ} \mathrm{C}\right)$ & 3.17 & 1.05 & 3.04 & 4.56 \\
\hline
\end{tabular}

Pocillopora damicornis sensu lato morphotypes corresponded to two different clades

Analysis of mitochondrial ORF for all samples revealed two clades corresponding to Pocillopora types 3c, 3e, 3g, 3h, and 7a (clade 2) for all samples from Djibouti and Pocillopora type 5 (clade 1) for samples from New Caledonia, Taiwan, and French Polynesia [33] (Additional file 2: Figure S1 and Additional file 1: Table $\mathrm{S} 1$ ). This is consistent with the known geographical distribution of Pocillopora lineages with a wide distribution of clade 1, i.e., types 4 and 5, namely Pocillopora damicornis and Pocillopora acuta, respectively, throughout the Pacific Ocean, and the presence of types 3 and 7 (P. damicornis sensu lato morphotype) in the Western Indian Ocean [32, 34].

\section{Symbiodinium assemblages revealed high specificity as well as high background diversity}

The relative proportions of Symbiodinium types in each coral sample were analyzed using high-throughput sequencing method. ITS2 amplicon sequencing with MiSeq yielded a total of 4,076,779 informative clusters. After clustering and filtering for OTUs containing less than 100 sequence tags, 53 clusters of ITS2 were obtained, corresponding to 3,990,373 sequences (Additional file 3: Table S2). Taxonomic affiliation was performed using blastn in comparison to NT followed by phylogenetic analysis. Maximum-likelihood trees confirmed the presence of clades A1, C1, C3, C15, D1, and $G$ with largely unresolved polytomies in the clade $C$ (Additional file 4: Figure S2), such as observed previously [53]. Nevertheless, the topology is congruent with previous works on the molecular taxonomy of Symbiodinium [54].

OTU richness assessed by Chao1 index was significantly different between sites (Kruskal-Wallis test, $\chi^{2}=$ $36.2, \mathrm{df}=3, p<0.0001)$ and particularly slightly higher in New Caledonia and Taiwan (see Additional file 5: Table S3). Moreover, Shannon diversity index was significantly different between sites (Kruskal-Wallis test, $\chi^{2}=58.9$, df $=3, \quad p<0.0001$ ) and particularly higher for French Polynesia compared to the others regions (Fig. 2a) (see Additional file 5: Table S3). Only one Symbiodinium clade was highly dominant per sample (accounting for more than 95\% of sequences) (Fig. 2b), suggesting high specificity for each association. In New Caledonia and Taiwan, Symbiodinium clade C1 was almost exclusively present in all samples. Clade D1 was dominant in French Polynesia samples (except for two samples), whereas a more diverse pattern is observed in Djibouti with a majority of clade D1 as well as a substantial proportion of clade A1, either as the main Symbiodinium clade or in association with D1. Accordingly, principal coordinate analysis based on Bray-Curtis dissimilarity index 


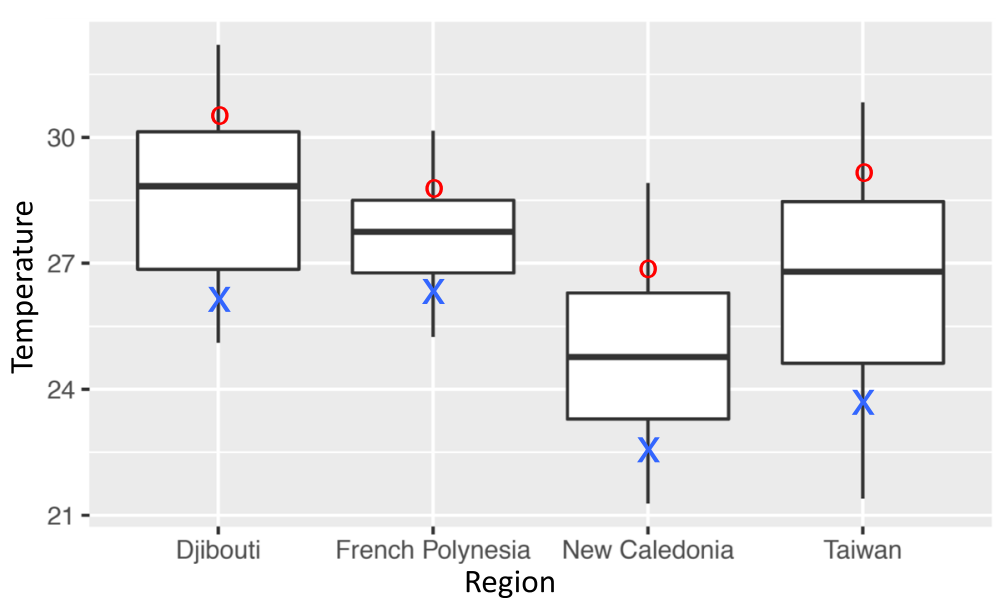

Fig. 1 Temperature distribution for the four sampled regions. The boxplots represent the lower and upper quartiles, the black lines represent the mean temperatures, and the whisker ends represent the minimal and maximal temperatures for each region. Blue crosses indicate the yearly mean temperatures of the three colder months, and red dots indicate the yearly mean temperatures of the three warmer months

followed this partitioning with two main groups (French Polynesia and Djibouti vs. Taiwan and New Caledonia) separated along the first axis (which explained $56.1 \%$ of the total variation) (Fig. 3). Samples from Djibouti forming a separate group along the second axis are hosting Symbiodinium clade A1. Samples from different host clades were overlapping on both axes.

\section{Bacterial microbiota was highly diverse with a small number of core taxa}

The bacterial microbiota of each coral sample was analyzed using 16S rRNA gene (V3V4) amplicon sequencing with MiSeq. It yielded a total of 8,198,530 informative clusters. After singleton filtering, we obtained 33,649
OTUs (representing a total of 7,108,067 sequences) that could be annotated using the Silva $16 \mathrm{~S}$ database. After filtering for chloroplast and non-bacterial sequences, we obtained 31,076 OTUs (Additional file 5: Table S3) representing 6,569,797 sequences. Notably, the 100 most abundant OTUs represented more than $90 \%$ of the whole sequences. OTU richness assessed by Chao1 index was the highest in French Polynesia and followed by a slightly higher level in Djibouti compared to samples of New Caledonia and Taiwan (Fig. 4a, Additional file 6: Table S4). Moreover, Shannon diversity index was significantly higher for Djibouti compared to the others regions. These results indicated a high number of rare OTUs in French Polynesia and higher evenness in Djibouti.

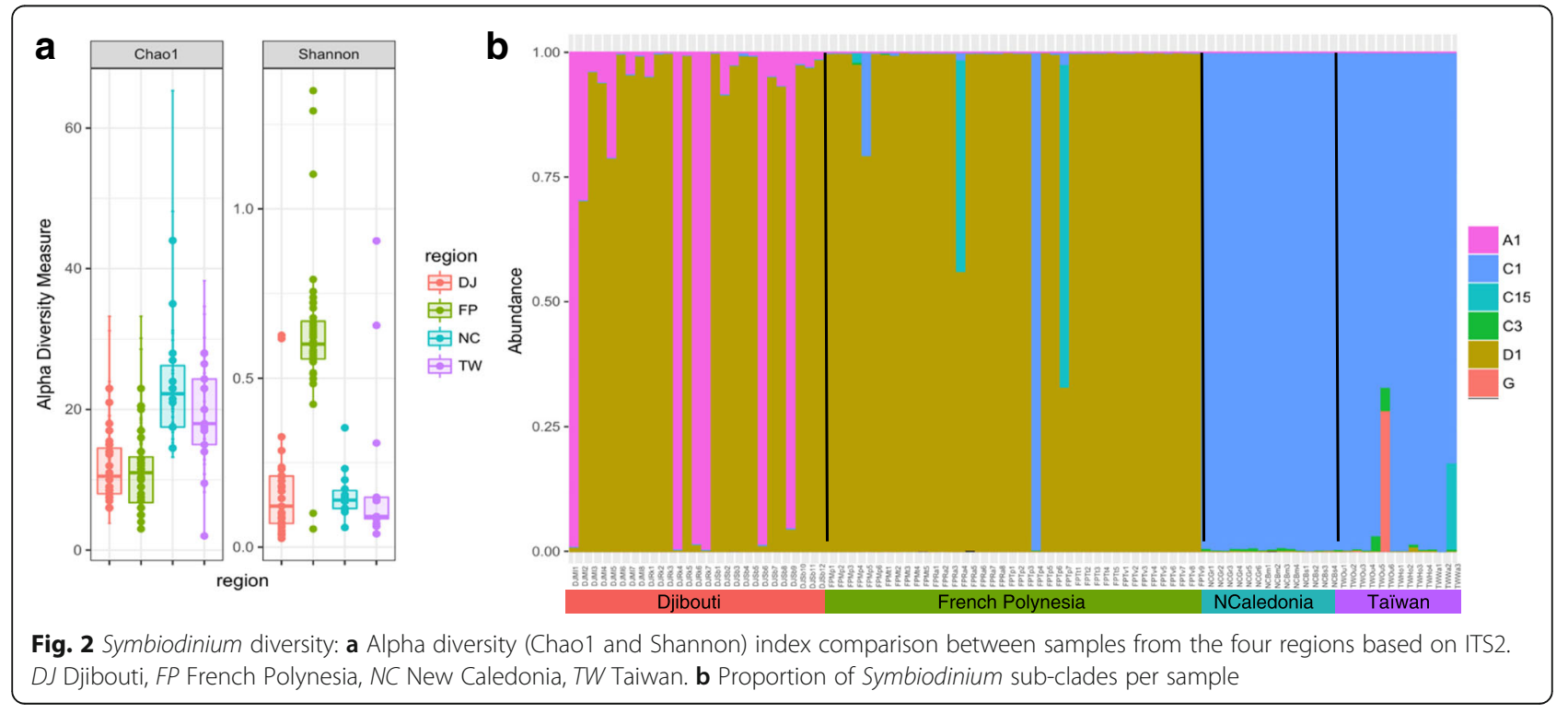




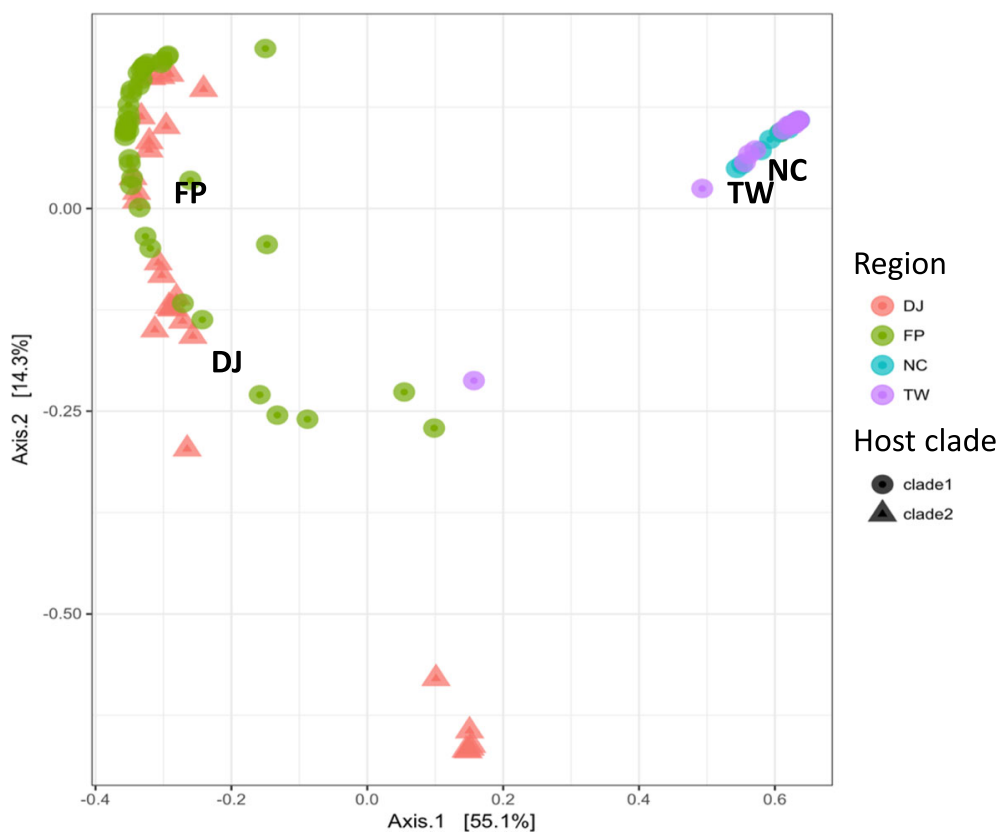

Fig. 3 Principal coordinate analysis of Bray-Curtis dissimilarities (ITS2) between all pairs of samples (colored by region of origin and shaped by Pocillopora host haplotype). DJ Djibouti, FP French Polynesia, NC New Caledonia, TW Taiwan. These axes represent the two synthetic variables explaining the most variation of the dataset

Phylum-level assignment of bacterial OTUs indicated the dominance of Proteobacteria in all samples (Fig. 4b). Within this phylum, the majority of sequences were affiliated to the genus Endozoicomonas (family Hahellaceae) representing $66.9 \%$ of the overall sequences (Additional file 7: Table S5). Three other genera, Arcobacter, Acinetobacter, and Sphingomonas were present at appreciable relative proportions (6.6, 1.9 , and $1 \%$, respectively, of total phyla tags).
Arcobacter (Campylobacteraceae) was particularly abundant in samples from Djibouti (25\% of sequence tags), whereas Acinetobacter (Moraxellaceae) represented $9.4 \%$ of the sequence tags in New Caledonia.

Among 227 families and 513 genera in the whole dataset, only the genus Endozoicomonas was common to all samples. We also considered as core phylotypes (at the family and genus level) the taxa shared by $50 \%$ of the individuals within each region (Table 3). Two additional

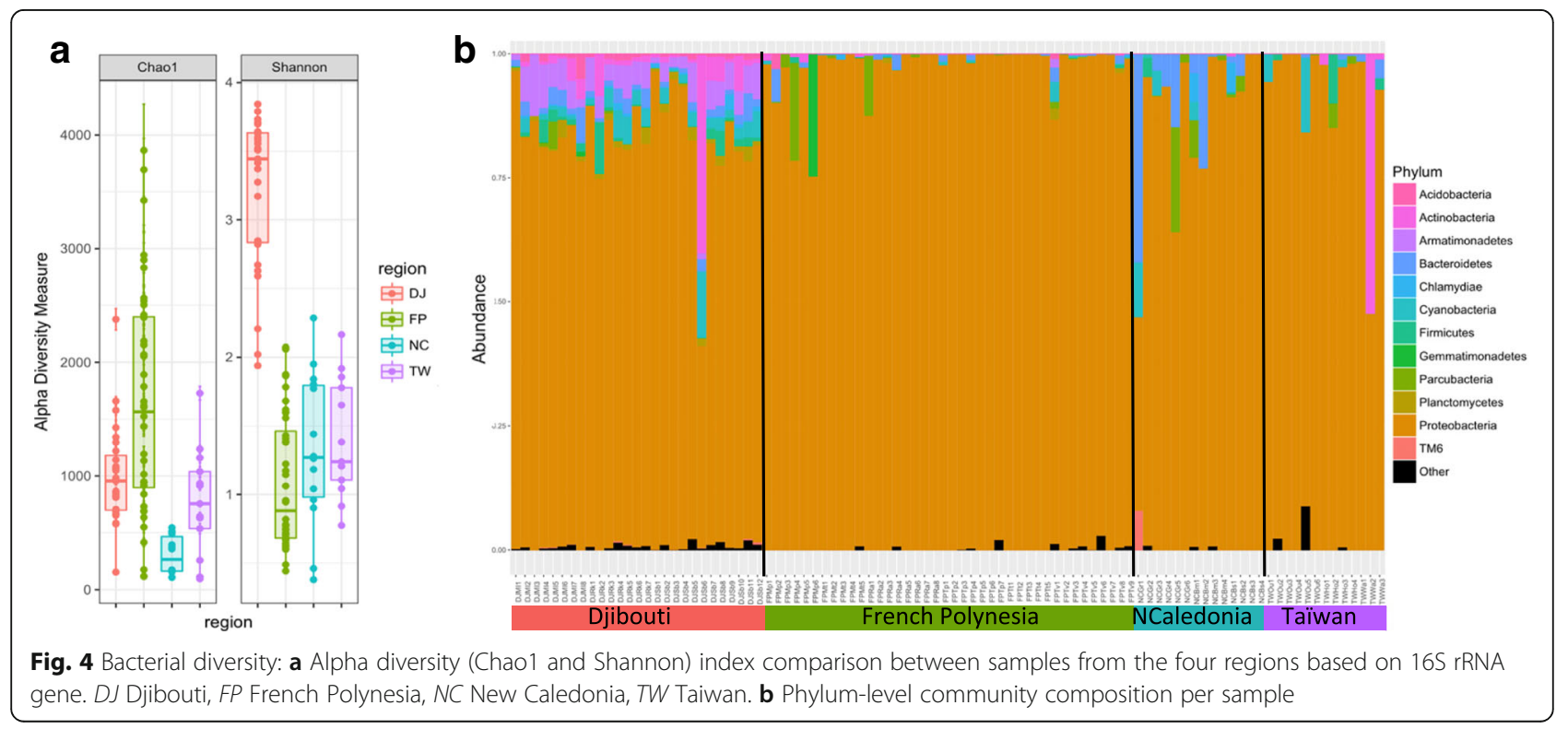


Table 3 Number of samples for each region for core taxa (shared by at least 50\% of samples within each region and 50\% of the overall samples) at the family and genus levels

\begin{tabular}{lllllll}
\hline Rank & Taxa & $\begin{array}{l}\text { DJ } \\
(27)\end{array}$ & $\begin{array}{l}\text { FP } \\
(40)\end{array}$ & $\begin{array}{l}\text { NC } \\
(14)\end{array}$ & $\begin{array}{l}\text { TW } \\
(13)\end{array}$ & $\begin{array}{l}\text { Total } \\
(94)\end{array}$ \\
\hline Family & Hahellaceae & 27 & 40 & 14 & 13 & 94 \\
& Moraxellaceae & 25 & 37 & 13 & 12 & 87 \\
& Comamonadaceae & 26 & 36 & 13 & 10 & 85 \\
& Campylobacteraceae & 25 & 34 & 13 & 12 & 84 \\
& Rhodobacteraceae & 25 & 36 & 11 & 9 & 81 \\
& Caulobacteraceae & 24 & 30 & 9 & 7 & 70 \\
& Sphingomonadaceae & 23 & 26 & 9 & 8 & 66 \\
Genus & Endozoicomonas & 27 & 40 & 14 & 13 & 94 \\
& Acinetobacter & 26 & 35 & 13 & 12 & 86 \\
& Arcobacter & 27 & 33 & 12 & 12 & 84
\end{tabular}

The total number of samples for each region is indicated into brackets. The family ranks also correspond to the core genus are indicated in bold

genera, Arcobacter and Acinetobacter, fall into this category in addition to Endozoicomonas. At the family level, four supplementary families, namely Comamonadaceae, Rhodobacteraceae, Caulobacteraceae, and Sphingomonadaceae, were shared by at least $50 \%$ of samples. In all cases, core taxa were among the 10 most abundant in the whole dataset (14 families and 6 genera were shared by at least $50 \%$ of the overall samples) (Additional file 7: Table S5).

Considering each region independently, strikingly much more taxa were shared between at least $50 \%$ of samples from Djibouti (27 families and 46 genera) (Additional file 7: Table S5), which could be linked to higher equitability. Twelve families and 5 genera were core to French Polynesia samples, 12 families and 4 genera for New Caledonia, whereas only 7 families and 3 genera were shared by at least $50 \%$ of samples from Taiwan (Additional file 7: Table S5).

Lastly, principal coordinate analysis based on BrayCurtis dissimilarity index showed a partitioning of bacterial communities by both host haplotype and region (Fig. 5). Samples from Djibouti (Pocillopora clade 2) and New Caledonia (Pocillopora clade 1) formed separate groups, whereas Taiwan and French Polynesia samples (clade 1) overlapped on the two principal axes.

\section{Symbiodinium communities were mostly influenced by minimal temperatures, whereas bacterial community structure was associated to host haplotype and mean temperatures}

To disentangle the influence of biogeography, temperature, and host haplotype (Additional file 1: Table S1) on coral communities of both Symbiodinium and bacteria, we computed redundancy analysis (RDA) and forward selection procedures. First, we performed RDAs on the whole dataset (geography, thermal regime, and host haplotype). A very high proportion (85\%) of Symbiodinium clade distribution was explained by the variables used in this study; this proportion was lower although important (36\%) for the bacterial OTU distributions (Fig. 6, Additional file 8: Table S6). Forward selection procedures were carried-out on the whole dataset to identify the significant variables (Additional file 1: Table S1) constraining the distribution of both communities. This study highlighted (i) that minimal temperature followed by host haplotype mostly constrained Symbiodinium distribution in the 94 samples $(p=0.001)$ and (ii) that in contrast, host haplotype followed by mean temperature then latitude mostly constrained bacteria distribution $(p=0.001)$.

\section{Discussion}

\section{Diversity of Pocillopora damicornis sensu lato samples}

In this study, we sampled Pocillopora damicornis sensu lato colonies in four regions and phylogenetic analyses revealed a complex pattern. Samples from French Polynesia, New Caledonia, and Taiwan corresponded to Pocillopora clade 1 (more precisely type 5, newly assigned to $P$. acuta sensu) [33, 34]. Samples from Djibouti corresponded to Pocillopora clade 2 (types 3 and 7) later assigned to SSH12 and SSH13 and all consistent with $P$. damicornis morphotype [32]. Morphological characters have been shown to be insufficient to discriminate species in the $P$. damicornis complex, and genetic markers are necessary to discriminate the species [33]. This species complex displays in addition high phenotypic plasticity and cryptic lineages [32]. Nevertheless, as we used a single mitochondrial marker for Pocillopora clade identification, we cannot completely rule out the possibility of mitochondrial introgression or hybridization that seem to be common within this genus $[55,56]$. Finally, although it was proposed that Symbiodinium assemblages may be useful for integrative taxonomy of Pocillopora species [57], we found in this study that Symbiodinium communities did not discriminate Pocillopora haplotypes.

\section{Diversity of coral microbiota}

The core microbiome can be broadly defined as the stable and consistent taxonomic groups associated to a particular habitat [58]. These commonly associated microbial communities are likely of ecological and functional importance in the holobiont fitness. The definition of the core microbiome in corals is variable among authors, ranging from 30 to $100 \%$ of shared bacterial phylotypes at all different taxonomic levels from kingdom to strain (reviewed in [3]). These studies already highlighted the high diversity and variability of microbial communities in corals. We defined here the 


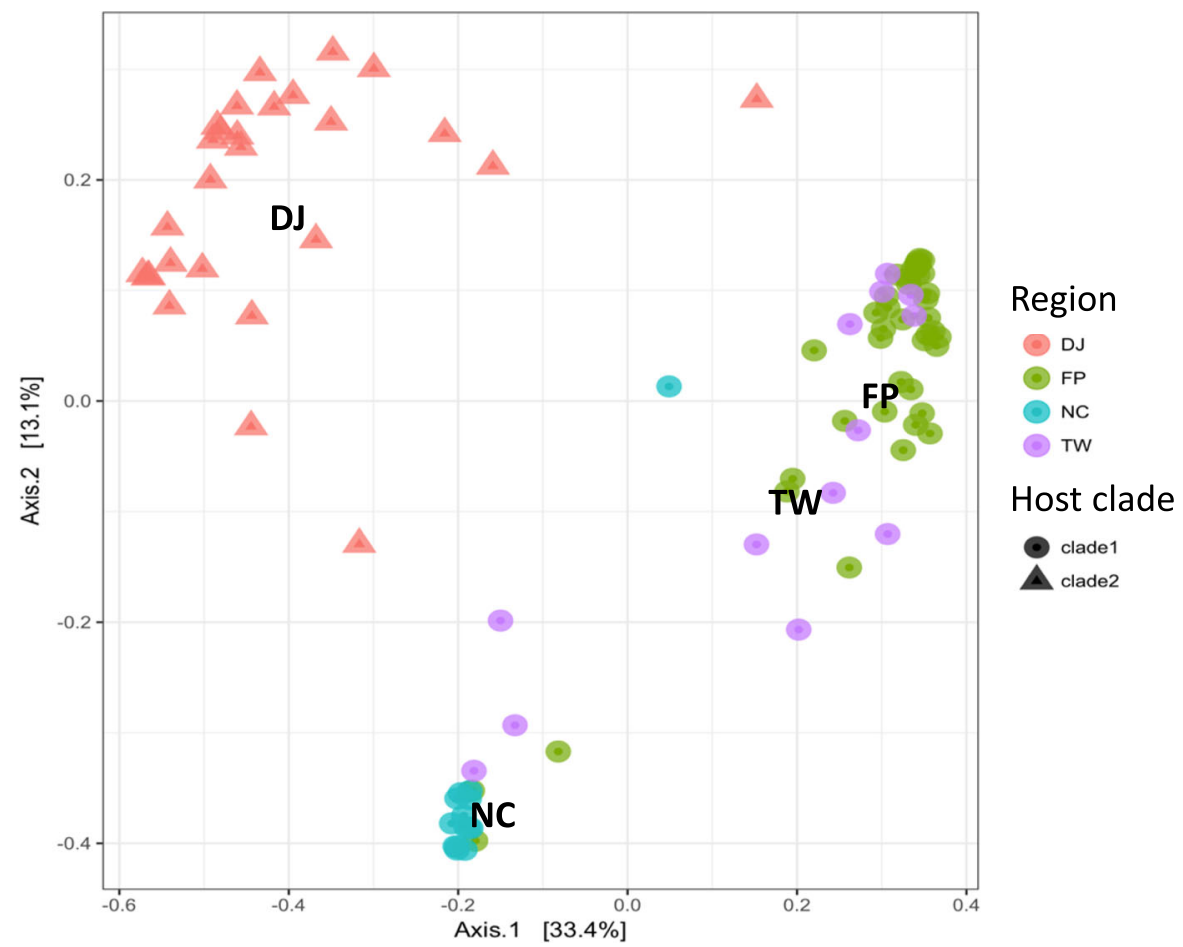

Fig. 5 Principal coordinate analysis of Bray-Curtis dissimilarity index (16S rRNA gene) between all pairs of samples (colors and shapes indicate region of origin and Pocillopora host haplotype, respectively). Axes represent the two synthetic variables explaining most variation in the dataset (about 46\%)

core microbiome as taxa (OTUs/genera/families) present in at least $50 \%$ of samples within each population and thus reflecting stable associations with $P$. damicornis sensu lato.

All core taxa of bacteria were among the most abundant in the dataset, which is in contradiction with previous study identifying rare taxa as ubiquitous endosymbionts [59]. Bacteria of the Endozoicomonas

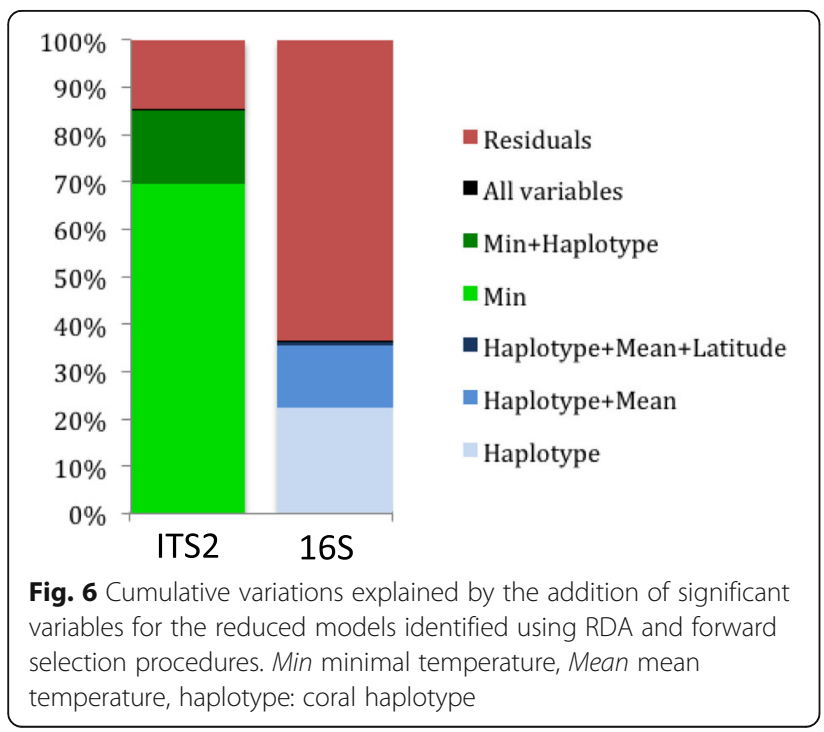

genus were present in all samples and were the most abundant in the whole dataset, making up from $33.3 \%$ of the total number of sequence tags in Djibouti (consistent with a higher evenness) to $87.4 \%$ in French Polynesia where rare OTUs were the most diverse. This group has been described for the first time only recently in marine slugs [60]. So far, they have been identified in numerous coral species and are now considered as ubiquitous endosymbionts of many marine host species (see [61] for a review). Notably, comparative genomic analysis of different strains of Endozoicomonas from different hosts suggests a common role in carbohydrate cycling with potential specificities in amino-acid synthesis [62]. In addition, Acinetobacter and Arcobacter were respectively present in 86 and 84 samples over 94 and were the third and second most abundant genus after Endozoicomonas. Although considered as a terrestrial bacteria, Acinetobacter (gamma-proteobacteria) can be dominant in bleached corals [63]. It has also been identified in healthy corals where it can be abundant [64-66], but its function remains elusive. Bacteria of the genus Arcobacter (epsilon-proteobacteria) are associated to a wide range of habitats, as free-living or pathogenic, and are especially abundant in marine environments [67] and have been identified specifically in diseased corals in some studies [68], sometimes also in healthy samples [69], and has been show to increase during pathogenesis 
[70, 71]. Arcobacter has also been found in high abundances in necrotic sponges [72] as well as moribund oysters [73] where it is associated with decreased bacterial diversity and may act as an opportunistic pathogen. Although detectable at background abundances in the majority of samples, Arcobacter was highly abundant in all samples from Djibouti (25\% of sequence tags vs. less than $1 \%$ in the other regions), indicating that this genus can also be abundant in healthy hosts and moreover associated with high bacterial diversity.

Metabarcoding targeting ITS2 provides highly sensitive measurements of Symbiodinium diversity and relative proportions [42]. It was used with 454-pyrosequencing $[74,75]$ and more recently with Illumina MiSeq sequencing [76]. Although we did not find ubiquitous clades for the whole samples, we showed using MiSeq sequencing striking differences in terms of Symbiodinium associations between populations. Clade D1 was dominant in French Polynesia. This is consistent with a recent study in Moorea that showed association with Symbiodinium clade D and few clade C [77]

Colonies from Djibouti were also mainly associated with clade D1, while clade $\mathrm{C} 1$ was dominant in Taiwan and New Caledonia. To our knowledge, this is the first study of symbiotic communities associated with Pocillopora in Djibouti, New Caledonia, and Taiwan. A comparative study of Symbiodinium clades associated with scleractinian corals from the Persian Gulf with annual temperatures from 16 up to $36{ }^{\circ} \mathrm{C}$ revealed the dominance of clade $\mathrm{C} 3$ associated with a lower proportion of $\mathrm{A} 1$ and minor quantities of $\mathrm{C} 15$, whereas clade D was not detected [78].

Even if one single clade was dominant in almost all samples, we detected background abundances of the other clades in all regions constituting the so called "Symbiodinium rare biosphere" [74]. The cryptic diversity that we reported here is actually very high $\left(\mathrm{H}^{\prime}\right.$ Shannon index up to 0.6 for French Polynesia samples, Fig. 2a) and falls into a similar range such as that reported in the latter work for three Pocilloporid species [79]. Such high diversity can potentially confer higher adaptive potential to their hosts through redundant or complementary symbiotic functions and/or potential for symbiont switching or shuffling [80]. High-throughput methods (ITS metabarcoding using 454) applied to the generalist and environmentally sensitive Acropora species also revealed the same pattern across Western Australia with clade $\mathrm{C}$ being dominant in all samples with background abundances of other clades [75].

Finally, bacterial communities in corals may also be shaped by the presence and type of photosymbionts [81] through the use of DMSP released by the algae [82], but at a finer scale, we could not find any relationship for the same host species between Symbiodinium type and bacterial communities as was also the case in Seriatopora hystrix [28]. In addition, we observed contrasting patterns in terms of alpha diversity between the Symbiodinium and bacteria communities, with notably an opposite pattern on the Shannon index for samples from Djibouti (highest Shannon index for 16S, Fig. 2a) and French Polynesia (highest Shannon index for ITS2, Fig. 4a). Previous work in Isopora palifera at the seasonal scale also revealed important variations in Shannon diversity that are uncoupled from changes in Symbiodinium community composition [64].

\section{Influence of geography on coral microbiota is very low}

Because we found different microbiota composition between samples, we used redundancy analyses in order to identify variables that significantly constrained their composition. We first found that the influence of geography was low, since longitude had no significant effect and the effect of latitude in our dataset was null for Symbiodinium assemblages and was marginal on bacterial communities (less than $1 \%$ when added to the variance explained by host haplotype and mean temperature). In contradiction with this result, geographic clustering of symbionts is expected to be high in brooding species with vertical transmission, compared to those with horizontal transmission that would in contrary favor propagation of locally adapted symbionts. Pocillopora damicornis is a hermaphrodite brooder [83, 84] thus transmitting its symbionts vertically [85] and is able to release sexual as well as parthenogenetic larvae [86, 87]. However, these results are similar to others studies showing that bacterial communities associated with different coral species are stable through space and time [2]. Thus, we hypothesize that low parental effect on symbiont communities may be explained by the relatively high connectivity and long-range dispersal for this species compared to other brooders [35, 88], which would mitigate the effect of geography and allow higher symbiont mixing with the local microbial environment.

\section{Influence of host haplotype is higher for bacterial communities than for Symbiodinium}

Although we did not find a significant link between microbiota and geography, we highlighted links with host haplotypes, particularly for bacterial microbiota. As the two host clades sampled in this study were from potentially different microbial environments, we cannot rule out a confounding effect between host haplotype and environmental communities present in the seawater at the time of larval settlement and bacterial microbiota acquisition. Nevertheless, others 
studies observed that host genotypes might influence bacterial microbiota, since (i) different coral species harbored different microbiota composition [2] and (ii) differential specificity between closely related corals and abundant Endozoicomonas endosymbionts were found across global scales [89].

In contrast, we found a significant but less important link between Symbiodinium and host haplotype. This observation might also be linked to the adaptive bleaching hypothesis, which proposes that coral bleaching is an adaptive mechanism through the modification of Symbiodinium composition, with acquisition of clades with higher thermal tolerances [90]. For example, endosymbiotic flexibility (the ability of a coral species to associate with multiple Symbiodinium clades) was observed to be linked with resistance [15]. In addition, Pocillopora is a generalist host, displaying a high intraspecific and interspecific flexibility in terms of Symbiodinium assemblages (mainly among clades A, C, and D) [91].

\section{Influence of temperature is higher for Symbiodinium than for bacterial microbiota}

Although host genotypes mostly constrained bacterial assemblages, we also found a significant link with mean temperatures. Interestingly, reciprocal transplants of Acropora corals at a reduced geographic scale revealed as well that their microbiome were different across thermally variable habitats and changed over time after transplantation [76]. As a consequence, bacterial communities might be linked to heat tolerance of their coral hosts, but further studies of their dynamics during a thermal stress are needed to understand their contribution to the holobiont response.

Strikingly, redundancy analysis revealed that most variation in Symbiodinium communities was actually explained by annual minimal temperatures (70\%), whereas we observed no significant correlation with mean, maximal, or annual fluctuations of temperatures. In Acropora, it has been shown experimentally that Symbiodinium type alters larvae settlement in a temperature-dependent fashion [92]. In the latter work, lower temperatures and not higher temperatures adversely affected recruitment by reducing larval survival and settlement. Accordingly, we propose that host/Symbiodinium associations are stable in space at a regional scale and are actually more sensitive to a minimal, threshold temperature, than to annual variations or to maximal temperatures.

In particular, clade $\mathrm{D}$ is common in all areas colonized by scleractinian corals [93], and many studies have shown that it confers higher thermotolerance to its host through photoprotection $[94,95]$ and that it increases in proportion after bleaching events [20, 95, 96]. Clade D is thus commonly considered as stress resistant and potentially opportunistic for compromised corals facing stressful conditions [97]. Nevertheless and in accordance to the link we observed with minimal temperatures, some studies have revealed that cold stress may be detrimental for coral harboring this symbiont $[98,99]$. More recently, it has been shown experimentally that clade D1a suffered more photodamages at low temperatures than clade C3 [100]. Thus, it seems that clade D may not display higher plasticity in terms of thermal range, but rather that it is only adapted to hot thermal environments. Because climate changes will not only be associated with global increase of sea surface temperatures, but also to extreme thermal events including cold episodes [101], further studies are required to understand the potential response of coral reef in the future, particularly for regions with highly fluctuating thermal regimes and low temperature thresholds.

\section{Conclusions}

The hologenome theory of evolution reboots elements of the Lamarckian evolution and has been thus a matter of much debate (reviewed in [7, 102]). Although the host genome follows a Mendelian framework, potential changes in microbial assemblages may be inherited to the next generation. Conversely, for the selection to operate on holobiont phenotypes at evolutionary scales, specificity of the interaction through coevolution between partners would be expected.

Using combined high-throughput barcoding approaches for both bacterial and Symbiodinium communities, we showed that variation in Symbiodinium composition is mostly explained by thermal regime, especially minimal temperatures, whereas bacterial communities are much less related to temperature modifications. In this context, we propose that Symbiodinium types might confer more enhanced adaptive capacities to temperature modifications than the bacterial microbiota. However, Symbiodinium clade D was known to be adapted to high temperature, and we found a negative relationship with low temperatures, suggesting low plasticity for this clade. Such low plasticity might limit the adaptive capabilities of a coral associated to clade D and living in highly variable thermal regime. However, a high background diversity of Symbiodinium was also observed, providing the potential for coral colonies to adapt or acclimatize to future environmental changes via symbiont shuffling (i.e., changes in the relative proportion of Symbiodinium types constituting the within host community).

Our study may thus contribute to new insights into the importance of microbial (i.e., bacterial and Symbiodinium) communities for holobiont functioning as well as the relative importance of host and environmental factors in shaping the interaction. 


\section{Additional files}

Additional file 1: Table S1. Sample metadata including geographic and abiotic variables (temperature descriptors) as well as Pocillopora haplotype identification. (XLSX 55 kb)

Additional file 2 Figure S1. Maximum-likelihood tree of the mitochondrial ORF-defining Pocillopora types. Numbers are bootstraps (\%) reflecting clade support. (PPTX 307 kb)

Additional file 3: Table S2. Symbiodinium OTU table with sequence tag counts per sample and taxonomic affiliation (XLSX $62 \mathrm{~kb}$ )

Additional file 4: Figure S2. Maximum-likelihood tree of the 53 Symbiodinium OTUs based on ITS2, together with GenBank representatives of each identified clade. Numbers are bootstraps (\%) reflecting clade support. (PPTX $438 \mathrm{~kb}$ )

Additional file 5: Table S3. Bacterial OTU table with sequence tag counts per sample and taxonomic affiliation. (XLSX 49 kb)

Additional file 6: Table S4. Diversity indices calculated on bacterial diversity for each sample and statistical analyses of differences between regions. (XLSX $136 \mathrm{~kb}$ )

Additional file 7: Table S5. Number of bacterial sequences and positive samples for each region at the family and genus levels. Taxa shared by at least $50 \%$ of samples in one population are colored in light gray, whereas taxa shared by at least $50 \%$ of the overall samples are colored in dark gray. We considered as core microbiota the taxa shared by $50 \%$ of samples for each of the four populations (regions) studied. (XLSX $128 \mathrm{~kb})$

Additional file 8: Table S6. Variations in bacterial (16S rRNA gene) and Symbiodinium (ITS2) communities explained by the addition of significant variables for the reduced models identified using RDA and forwardselection procedures. (XLSX $38 \mathrm{~kb}$ )

\section{Acknowledgements}

We would like to thank Lorenzo Bramanti, Pauline Bosserelle, and Tung-Yung Fan for their help in the coral sampling. We are grateful to the genotoul bioinformatics platform Toulouse Midi-Pyrenees and Sigenae group for providing help and computing resources through Galaxy instance http://sigenaeworkbench.toulouse.inrafi.

\section{Funding}

This project has been funded by the ADACNI programme of the French National Research Agency (ANR) (project no. ANR-12-ADAP-0016; http:// adacni.imbe.fr).

\section{Availability of data and materials}

The datasets generated during the current study are available in the Sequence Read Archive repository under BioProject ID PRJNA393088, BioSample ID SUB2829485 (to be released upon publication).

\section{Authors' contributions}

$E T, J V D, M A, D A, F B$, and GM were involved in the study concept and design. JVD and MA were involved in the collection of samples. KBR, CC, FB, DA, MP and ET were involved in the data acquisition and analysis. ET drafted the manuscript, and all authors contributed to critical revisions and approved the final manuscript.

\section{Ethics approval and consent to participate}

Not applicable.

\section{Consent for publication}

Not applicable.

\section{Competing interests}

The authors declare that they have no competing interests.

\section{Publisher's Note}

Springer Nature remains neutral with regard to jurisdictional claims in published maps and institutional affiliations.

\section{Author details}

IHPE, UMR 5244, University of Perpignan Via Domitia, CNRS, IFREMER, University of Montpellier, Perpignan, France. ${ }^{2}$ ENTROPIE, UMR 9220 \& Laboratoire d'Excellence CORAIL, IRD, University of Perpignan Via Domitia, Perpignan, France. ${ }^{3}$ ISEM, UMR 5554, CNRS, University of Montpellier, IRD, EPHE, Sète, France. ${ }^{4}$ IMBE, UMR 7263, Aix Marseille University, CNRS, IRD, Avignon University, Marseille, France.

Received: 19 July 2017 Accepted: 11 February 2018

Published online: 20 February 2018

\section{References}

1. Margulis L, Fester R. Symbiosis as a source of evolutionary innovation. Cambridge: MIT Press; 1991. pp 2-14.

2. Rohwer F, Seguritan $V$, Azam F. Diversity and distribution of coral-associated bacteria. Marine Ecology Progress. 2002;243:1-10.

3. Hernandez-Agreda A, Gates RD, Ainsworth TD. Defining the core microbiome in corals' microbial soup. Trends Microbiol. 2017;25(2):125-40.

4. Jefferson R. The Hologenome. Agriculture, environment and the developing world: a future of PCR. New York: Cold Spring Harbor; 1994

5. Rosenberg E, Koren O, Reshef L, Efrony R, Zilber-Rosenberg I. The role of microorganisms in coral health, disease and evolution. Nat Rev Micro. 2007;5:355-62.

6. Zilber-Rosenberg I, Rosenberg E. Role of microorganisms in the evolution of animals and plants: the hologenome theory of evolution. FEMS Microbiol Rev. 2008:32:723-35.

7. Bordenstein SR, Theis KR. Host biology in light of the microbiome: ten principles of holobionts and hologenomes. PLoS Biol. 2015;13: e1002226.

8. Guerrero R, Margulis L, Berlanga M. Symbiogenesis: the holobiont as a unit of evolution. Int Microbiol. 2013:16:133-43.

9. McFall-Ngai M, Hadfield MG, Bosch TC, Carey HV, Domazet-Lošo T, Douglas AE, Dubilier N, Eberl G, Fukami T, Gilbert SF. Animals in a bacterial world, a new imperative for the life sciences. Proc Natl Acad Sci U S A. 2013:110:3229-36.

10. Bosch TCG, McFall-Ngai MJ. Metaorganisms as the new frontier. Zoology. 2011;114:185-90.

11. Blackall LL, Wilson B, van Oppen MJH. Coral-the world's most diverse symbiotic ecosystem. Mol Ecol. 2015;24:5330-47.

12. Muscatine $L$, Porter JW. Reef corals: mutualistic symbioses adapted to nutrient-poor environments. Bioscience. 1977;27:454-60.

13. Davy SK, Allemand D, Weis VM. Cell biology of cnidarian-dinoflagellate symbiosis. Microbiol Mol Biol Rev. 2012;76:229-61.

14. DeSalvo MK, Sunagawa S, Fisher PL, Voolstra CR, Iglesias-Prieto R, Medina M. Coral host transcriptomic states are correlated with Symbiodiniumgenotypes. Mol Ecol. 2010;19:1174-86.

15. Baker AC. Flexibility and specificity in coral-algal symbiosis: diversity, ecology, and biogeography of Symbiodinium. Annual Review of Ecology. 2003;34:661-89.

16. Coffroth MA, Santos SR. Genetic diversity of symbiotic dinoflagellates in the genus Symbiodinium. Protist. 2005;156:19-34.

17. Mieog JC, van Oppen M, Cantin NE, Stam WT. Real-time PCR reveals a high incidence of Symbiodinium clade D at low levels in four scleractinian corals across the Great Barrier Reef: implications for symbiont shuffling. Coral Reefs. 2007:26:449-57.

18. Rouzé H, Lecellier G, Saulnier D, Berteaux-Lecellier V. Symbiodinium clades A and $\mathrm{D}$ differentially predispose Acropora cythereato disease and vibrio spp. colonization. Ecol Evol. 2016;6:560-72

19. Weis $V$, Reynolds W, deBoer M, Krupp D. Host-symbiont specificity during onset of symbiosis between the dinoflagellates Symbiodinium spp. and planula larvae of the scleractinian coral Fungia scutaria. Coral Reefs. 2001;20:301-8.

20. Baker AC, Starger CJ, McClanahan TR, Glynn PW. Coral reefs: corals' adaptive response to climate change. Nature. 2004:430:741.

21. Jones AM, Berkelmans R, van Oppen MJH, Mieog JC, Sinclair W. A community change in the algal endosymbionts of a scleractinian coral following a natural bleaching event: field evidence of acclimatization. Proc $R$ Soc B-Biol Sci. 2008:275:1359-65.

22. Thornhill DJ, Lajeunesse TC, Kemp DW, Fitt WK. Multi-year, seasonal genotypic surveys of coral-algal symbioses reveal prevalent stability or postbleaching reversion. Mar Biol. 2006;148:711-22. 
23. Littman R, Singh Y, Willis BL, Ahmad J, Pfeffer C, Musarrat J, Bourne DG, Ehtesham NZ, Hasnain SE. Diversities of coral-associated bacteria differ with location, but not species, for three acroporid corals on the Great Barrier Reef. FEMS Microbiol Ecol. 2009;68:152-63.

24. Cróquer A, Bastidas C, Elliott A, Sweet M. Bacterial assemblages shifts from healthy to yellow band disease states in the dominant reef coral Montastraea faveolata. Environ Microbiol Rep. 2013;5:90-6.

25. Meyer JL, Rodgers JM, Dillard BA, Paul VJ, Teplitski M. Epimicrobiota associated with the decay and recovery of Orbicella corals exhibiting dark spot syndrome. Front Microbiol. 2016;7:893.

26. Sato Y, Willis BL, Bourne DG. Successional changes in bacterial communities during the development of black band disease on the reef coral, Montipora hispida. ISME J. 2009:4:203-14.

27. Bourne D, Bourne D, lida Y, lida Y, Uthicke S, Uthicke S, Smith-Keune C, Smith-Keune C. Changes in coral-associated microbial communities during a bleaching event. ISME J. 2007;2:350-63.

28. Pantos O, Bongaerts P, Dennis PG, Tyson GW, Hoegh-Guldberg O. Habitatspecific environmental conditions primarily control the microbiomes of the coral Seriatopora hystrix. ISME J. 2015;9:1916-27.

29. Carpenter KE, Abrar M, Aeby G, Aronson RB. One-third of reef-building corals face elevated extinction risk from climate change and local impacts. Science. 2008;321:560-3.

30. Hughes TP, Kerry JT, Álvarez-Noriega M, Álvarez-Romero JG, Anderson KD, Baird AH, Babcock RC, Beger M, Bellwood DR, Berkelmans R, Bridge TC, Butler IR, Byrne M, Cantin NE, Comeau S, Connolly SR, Cumming GS, Dalton SJ, DiazPulido G, Eakin CM, Figueira WF, Gilmour JP, Harrison HB, Heron SF, Hoey AS, JPA H, Hoogenboom MO, Kennedy EV, Kuo C-Y, Lough JM, et al. Global warming and recurrent mass bleaching of corals. Nature. 2017;543:373-7.

31. van Woesik R, Sakai K, Ganase A, Loya Y. Revisiting the winners and the losers a decade after coral bleaching. Mar Ecol Prog Ser. 2011;434:67-76.

32. Gélin P, Postaire B, Fauvelot C, Magalon H. Reevaluating species number distribution and endemism of the coral genus Pocillopora Lamarck, 1816 using species delimitation methods and microsatellites. Mol Phylogenet Evol. 2017;109:430-46.

33. Pinzón JH, Sampayo E, Cox E, Chauka LJ, Chen CA, Voolstra CR, LaJeunesse TC. Blind to morphology: genetics identifies several widespread ecologically common species and few endemics among Indo-Pacific cauliflower corals (Pocillopora, Scleractinia). J Biogeogr. 2013;40:1595-608.

34. Schmidt-Roach S, Miller KJ, Lundgren P, Andreakis N. With eyes wide open: a revision of species within and closely related to the Pocillopora damicornisspecies complex (Scleractinia; Pocilloporidae) using morphology and genetics. Zool J Linnean Soc. 2014;170:1-33.

35. Adjeroud M, Guérécheau A, Vidal-Dupiol J, Flot J-F, Arnaud-Haond S, Bonhomme F. Genetic diversity, clonality and connectivity in the scleractinian coral Pocillopora damicornis: a multi-scale analysis in an insular, fragmented reef system. Mar Biol. 2013;161:531-41.

36. Flot JF. Vers une taxonomie moléculaire des coraux du genre Pocillopora. 2007.

37. Winnepenninckx B, Backeljau T, De Wachter R. Extraction of high molecular weight DNA from molluscs. Trends Genet. 1993;9:407.

38. Flot J-F, Tillier S. The mitochondrial genome of Pocillopora (Cnidaria: Scleractinia) contains two variable regions: the putative D-loop and a novel ORF of unknown function. Gene. 2007:401:80-7.

39. Tamura K, Stecher G, Peterson D, Filipski A, Kumar S. MEGA6: molecular evolutionary genetics analysis version 6.0. Mol Biol Evol. 2013;30:2725-9.

40. Klindworth A, Pruesse E, Schweer T, Peplies J, Quast C, Horn M, Glockner FO. Evaluation of general $16 \mathrm{~S}$ ribosomal RNA gene PCR primers for classical and next-generation sequencing-based diversity studies. Nucleic Acids Res. 2012;41:e1.

41. Lajeunesse TC, Trench RK. Biogeography of two species of Symbiodinium (Freudenthal) inhabiting the intertidal sea anemone Anthopleura elegantissima (Brandt). Biol Bull. 2000;199:126-34

42. Quigley KM, Quigley KM, Davies SW, Davies SW, Kenkel CD, Kenkel CD Willis BL, Willis BL, Matz MV, Matz MV, Bay LK, Bay LK. Deep-sequencing method for quantifying background abundances of Symbiodinium types: exploring the rare Symbiodinium biosphere in reef-building corals. PLoS One. 2014;9:e94297.

43. Escudié F, Auer L, Bernard M, Mariadassou M, Cauquil L, Vidal K, Maman S, Hernandez-Raquet G, Combes S, Pascal G. FROGS: find, rapidly, OTUs with galaxy solution. Bioinformatics. 2017; https://doi.org/10.1093/bioinformatics/btx791.

44. Magoč T, Salzberg SL. FLASH: fast length adjustment of short reads to improve genome assemblies. Bioinformatics. 2011;27:2957-63.
45. Martin M. Cutadapt removes adapter sequences from high-throughput sequencing reads. EMBnetjournal. 2011;17:10.

46. Mahé F, Rognes T, Quince C, De Vargas C, Dunthorn M. Swarm: robust and fast clustering method for amplicon-based studies. PeerJ. 2014;2:e593.

47. Rognes T, Flouri T, Nichols B, Quince C, Mahé F. VSEARCH: a versatile open source tool for metagenomics. PeerJ. 2016;4:e2584

48. Altschul SF, Gish W, Miller W, Myers EW, Lipman DJ. Basic local alignment search tool. J Mol Biol. 1990;215:403-10.

49. Team RC. R Core team. 2013. R: a language and environment for statistical computing. R Foundation for Statistical Computing, Vienna. 2013.

50. McMurdie PJ, Holmes S. Phyloseq: an R package for reproducible interactive analysis and graphics of microbiome census data. PLoS One. 2013;8:e61217.

51. Ramette A. Multivariate analyses in microbial ecology. FEMS Microbiol Ecol. 2007:62:142-60.

52. Legendre P, Gallagher ED. Ecologically meaningful transformations for ordination of species data. Oecologia. 2001;129:271-80.

53. Lajeunesse TC. "Species" radiations of symbiotic dinoflagellates in the Atlantic and Indo-Pacific since the Miocene-Pliocene transition. Mol Biol Evol. 2004;22:570-81

54. Pochon X, Montoya-Burgos JI, Stadelmann B, Pawlowski J. Molecular phylogeny, evolutionary rates, and divergence timing of the symbiotic dinoflagellate genus Symbiodinium. Mol Phylogenet Evol. 2006;38:20-30.

55. Combosch DJ, Vollmer SV. Trans-Pacific RAD-Seq population genomics confirms introgressive hybridization in Eastern Pacific Pocillopora corals. Mol Phylogenet Evol. 2015;88:154-62.

56. Combosch DJ, Guzman HM, Schuhmacher H, Vollmer SV. Interspecific hybridization and restricted trans-Pacific gene flow in the tropical Eastern Pacific Pocillopora. Mol Ecol. 2008;17:1304-12.

57. Pinzón JH, LaJeunesse TC. Species delimitation of common reef corals in the genus Pocillopora using nucleotide sequence phylogenies, population genetics and symbiosis ecology. Mol Ecol. 2011;20:311-25.

58. Shade A, Handelsman J. Beyond the Venn diagram: the hunt for a core microbiome. Environ Microbiol. 2011:14:4-12.

59. D Ainsworth T, Krause L, Bridge T, Torda G, Raina J-B, Zakrzewski M, Gates RD, Padilla-Gamiño JL, Spalding HL, Smith C, Woolsey ES, Bourne DG, Bongaerts P, Hoegh-Guldberg O, Leggat W. The coral core microbiome identifies rare bacterial taxa as ubiquitous endosymbionts. ISME J. 2015;9:2261-74.

60. Kurahashi M, Yokota A. Endozoicomonas elysicola gen. nov., sp. nov., a gamma-proteobacterium isolated from the sea slug Elysia ornata. Syst Appl Microbiol. 2007;30:202-6.

61. Neave MJ, Apprill A, Ferrier-Pages C, Voolstra CR. Diversity and function of prevalent symbiotic marine bacteria in the genus Endozoicomonas. Appl Microbiol Biotechnol. 2016;100:8315-24.

62. Neave MJ, Michell CT, Apprill A, Voolstra CR. Endozoicomonas genomes reveal functional adaptation and plasticity in bacterial strains symbiotically associated with diverse marine hosts. Sci Rep. 2017;7:40579.

63. Koren O, Rosenberg E. Bacteria associated with the bleached and cave coral Oculina patagonica. Microb Ecol. 2008:55:523-9.

64. Chen C-P, Tseng C-H, Chen CA, Tang S-L. The dynamics of microbial partnerships in the coral Isopora palifera. ISME J. 2011:5:728-40.

65. Li J, Chen Q, Long L-J, Dong J-D, Yang J, Zhang S. Bacterial dynamics within the mucus, tissue and skeleton of the coral Porites Lutea during different seasons. Sci Rep. 2014;4:7320.

66. Morrow KM, Moss AG, Chadwick NE, Liles MR. Bacterial associates of two Caribbean coral species reveal species-specific distribution and geographic variability. Appl Environ Microbiol. 2012;78:6438-49.

67. Miller WG, Parker CT, Rubenfield M, Mendz GL, Wösten MMSM, Ussery DW, Stolz JF, Binnewies TT, Hallin PF, Wang G, Malek JA, Rogosin A, Stanker LH, Mandrell RE. The complete genome sequence and analysis of the epsilonproteobacterium Arcobacter butzleri. PLoS One. 2006:2:e1358.

68. Frias-Lopez J, Zerkle AL, Bonheyo GT, Fouke BW. Partitioning of bacteria communities between seawater and healthy, black band diseased, and dead coral surfaces. Appl Environ Microbiol. 2002;68:2214-28.

69. de Castro AP, Araújo SD, Reis AMM, Moura RL, Francini-Filho RB, Pappas G, Rodrigues TB, Thompson FL, Krüger RH. Bacterial community associated with healthy and diseased reef coral Mussismilia hispida from eastern Brazil. Microb Ecol. 2010;59:658-67.

70. Séré $M$, Wilkinson DA, Schleyer MH, Chabanet $P$, Quod J-P, Tortosa P. Characterisation of an atypical manifestation of black band disease on Porites lutea in the Western Indian Ocean. PeerJ. 2015;4:e2073. 
71. Sweet M, Bythell J. Ciliate and bacterial communities associated with White syndrome and Brown Band disease in reef-building corals. Environ Microbiol. 2012;14:2184-99.

72. Fan L, Liu M, Simister R, Webster NS, Thomas T. Marine microbial symbiosis heats up: the phylogenetic and functional response of a sponge holobiont to thermal stress. ISME J. 2013;7:991-1002.

73. Lokmer A, Mathias Wegner K. Hemolymph microbiome of Pacific oysters in response to temperature, temperature stress and infection. ISME J. 2014;9:670-82.

74. Boulotte NM, Dalton SJ, Carroll AG, Harrison PL, Putnam HM, Peplow LM, van Oppen MJ. Exploring the Symbiodinium rare biosphere provides evidence for symbiont switching in reef-building corals. ISME J. 2016;10: 2693-701.

75. Thomas L, Kendrick GA, Kennington WJ, Richards ZT, Stat M. Exploring Symbiodiniumdiversity and host specificity in Acropora corals from geographical extremes of Western Australia with 454 amplicon pyrosequencing. Mol Ecol. 2014;23:3113-26.

76. Ziegler M, Seneca FO, Yum LK, Palumbi SR, Voolstra CR. Bacterial community dynamics are linked to patterns of coral heat tolerance. Nat Comms. 2017:8:14213.

77. Rouzé H, Lecellier GJ, Saulnier D, Planes S, Gueguen Y, Wirshing HH, Berteaux-Lecellier V. Data S2: Symbiodinium 28S DNA sequences mentioned in the paper. PeerJ. 2017;5:e2856.

78. Hume B, D'Angelo C, Burt J, Baker AC, Riegl B, Wiedenmann J. Corals from the Persian/Arabian Gulf as models for thermotolerant reef-builders: prevalence of clade C3 Symbiodinium, host fluorescence and ex situ temperature tolerance. Mar Pollut Bull. 2013;72:313-22.

79. Weber L, DeForce E, Apprill A. Optimization of DNA extraction for advancing coral microbiota investigations. Microbiome. 2017:5:18.

80. Fabina NS, Putnam HM, Franklin EC, Stat M, Gates RD. Symbiotic specificity, association patterns, and function determine community responses to global changes: defining critical research areas for coralSymbiodiniumsymbioses. Glob Change Biol. 2013;19:3306-16.

81. Bourne DG, Bourne DG, Dennis PG, Dennis PG, Uthicke S, Uthicke S, Soo RM, Soo RM, Tyson GW, Tyson GW, Webster N, Webster N. Coral reef invertebrate microbiomes correlate with the presence of photosymbionts. ISME J. 2013;7:1452-8.

82. Raina J-B, Dinsdale EA, Willis BL, Bourne DG. Do the organic sulfur compounds DMSP and DMS drive coral microbial associations? Trends Microbiol. 2010;18:101-8.

83. Fan TY, Lin KH, Kuo FW, Soong K, Liu LL. Diel patterns of larval release by five brooding scleractinian corals. Mar Ecol Prog Ser. 2006;321:133-42.

84. Harrison PL, Wallace CC. Reproduction, dispersal and recruitment of scleractinian corals: Ecosystems of the world. Amsterdam: Ed. Z Dubinsky Elsevier; 1990. pp. 133-207.

85. Baird AH, Guest JR, Willis BL. Systematic and biogeographical patterns in the reproductive biology of scleractinian corals. Annu Rev Ecol Evol Syst. 2009; 40:551-71.

86. Whitaker K. Genetic evidence for mixed modes of reproduction in the coral Pocillopora damicornis and its effect on population structure. Mar Ecol Prog Ser. 2006:306:115-24

87. Yeoh S-R, Dai C-F. The production of sexual and asexual larvae within single broods of the scleractinian coral, Pocillopora damicornis. Mar Biol. 2009;157:351-9.

88. Gélin P, Fauvelot $\mathrm{C}$, Mehn V, Bureau S, Rouzé $H$, Magalon H. Superclone expansion, long-distance clonal dispersal and local genetic structuring in the coral Pocillopora damicornis type $\beta$ in Reunion Island, South Western Indian Ocean. PLoS One. 2017;12:e0169692.

89. Neave MJ, Rachmawati R, Xun L, Michell CT, Bourne DG, Apprill A, Voolstra CR. Differential specificity between closely related corals and abundant Endozoicomonas endosymbionts across global scales. ISME J. 2016;11:186-200.

90. Buddemeier RW, Fautin DG. Coral bleaching as an adaptive mechanism. Bioscience. 1993;43:320-6.

91. Putnam HM, Stat M, Pochon X, Gates RD. Endosymbiotic flexibility associates with environmental sensitivity in scleractinian corals. Proc R Soc B-Biol Sci. 2012;279:4352-61.

92. Winkler NS, Pandolfi JM, Sampayo EM. Symbiodinium identity alters the temperature-dependent settlement behaviour of Acropora millepora coral larvae before the onset of symbiosis. Proc Biol Sci. 2015;282:-20142260.
93. Knowlton N, Rohwer F. Multispecies microbial mutualisms on coral reefs: the host as a habitat. Am Nat. 2003;162:S51-62.

94. Jones A, Berkelmans R. The photokinetics of thermo-tolerance in Symbiodinium. Mar Ecol. 2012;33:490-8.

95. Rowan R. Coral bleaching: thermal adaptation in reef coral symbionts. Nature. 2004:430:742.

96. Fabricius KE, Mieog JC, Colin PL, Idip D, van Oppen MJH. Identity and diversity of coral endosymbionts (zooxanthellae) from three Palauan reefs with contrasting bleaching, temperature and shading histories. Mol Ecol. 2004;13:2445-58.

97. Stat M, Gates RD. Clade D Symbiodiniumin scleractinian corals: A "Nugget" of hope, a selfish opportunist, an ominous sign, or all of the above? Journal of Marine Biology. 2011;2011:1-9.

98. Roth MS, Goericke R, Deheyn DD. Cold induces acute stress but heat is ultimately more deleterious for the reef-building coral Acropora yongei. Sci Rep. 2012;2:240.

99. Tsang R, Ang P Jr. Cold temperature stress and predation effects on corals: their possible roles in structuring a nonreefal coral community. Coral Reefs. 2015;34:97-108.

100. Silverstein RN, Cunning R, Baker AC, Tenacious D. Symbiodiniumin clade D remain in reef corals at both high and low temperature extremes despite impairment. J Exp Biol. 2017:220:1192-6.

101. Kim B-M, Son S-W, Min S-K, Jeong J-H, Kim S-J, Zhang X, Shim T, Yoon J-H. Weakening of the stratospheric polar vortex by Arctic sea-ice loss. Nat Comms. 2013;5:4646.

102. Theis KR, Dheilly NM, Klassen JL, Brucker RM, Baines JF, Bosch TCG, Cryan JF, Gilbert SF, Goodnight CJ, Lloyd EA, Sapp J, Vandenkoornhuyse P, ZilberRosenberg I, Rosenberg E, Bordenstein SR. Getting the hologenome concept right: an eco-evolutionary framework for hosts and their microbiomes. mSystems. 2016;1:e00028-16.

\section{Submit your next manuscript to BioMed Central and we will help you at every step:}

- We accept pre-submission inquiries

- Our selector tool helps you to find the most relevant journal

- We provide round the clock customer support

- Convenient online submission

- Thorough peer review

- Inclusion in PubMed and all major indexing services

- Maximum visibility for your research

Submit your manuscript at www.biomedcentral.com/submit
Biomed Central 